\title{
Engineering and Sustainability: The Challenge of Integrating Social and Eth- ical Issues into a Technical Course
}

\section{Dr. Natasha A. Andrade, University of Maryland, College Park}

Dr. Natasha Andrade is a Lecturer in the Civil and Environmental Engineering Department at the University of Maryland College Park. Her responsibilities include teaching various undergraduate courses in environmental engineering (such as Engineering for Sustainability and Environmental Engineering Science) and conducting research focused on emerging organic pollutants and their environmental fate. She specializes in the production of stabilized biosolids, its use as a fertilizer and its impact on environmental pollution concerning organic contaminants. She has also specialized in redesigning engineering courses to make them more student-centered and encouraging of active learning. More recently, she started work on engineering education research that analyses the incorporation and effectiveness of engineering macroethics in-class activities that focus on sustainable development.

\section{Dr. David Tomblin, University of Maryland, College Park}

David is the director of the Science, Technology and Society program at the University of Maryland, College Park. He works with STEM majors on the ethical and social dimensions of science and technology. David also does public engagement with science and technology work with government agencies such as NASA, DOE, and NOAA. 
Engineering and Sustainability: The Challenge of Integrating Social and Ethical Issues into a

Technical Course

Dr. Natasha Andrade, University of Maryland

Dr. David Tomblin, University of Maryland

\begin{abstract}
Sustainability is increasingly being incorporated into engineering curriculums ${ }^{1,2}$, often due to ABET requirements ${ }^{3}$, but also due to faculty expertise. The United Nations recognizes that achieving sustainable development is only possible if a balance exists between the three dimensions of sustainability: social, economic, and environmental ${ }^{4}$. However, engineering programs can overlook the social dimension by focusing on technological solutions and conflating sustainable development with only environmental protection ${ }^{5,6}$.

This paper reports on the evolution of incorporating the social dimensions of sustainability into Engineering for Sustainability, a required sophomore-level course in a Civil and Environmental Engineering Department. The course was created in 2003, revised in 2010 ${ }^{7}$, and redesigned in 2015-2016. Throughout the history of the course, sustainability was mostly discussed as the application of the basic sciences to engineering issues focused on protecting the environment. Though social issues were present in some lectures, there was little emphasis on social dimensions until the course's redesign in 2015, when the design of sustainable infrastructure became the focus of the course. Activities that centered on the intersection of social issues, urbanization, and sustainable development were introduced in two class sections during a semester. These discussion-based activities have been revised every semester since their implementation in order to improve student learning outcomes, induce more thoughtful conversations among students, and invoke a deeper evaluation of the complexity of the current urban systems. However, it became evident that it was challenging to address important social issues, because of their complexity, in only two class sessions. Developing students' understanding of social and ethical issues related to sustainable development requires full engagement of the course instructor, considerable preparation time, and the development of curriculum that intentionally brings social dimensions of sustainable technology to the forefront.

The 2015 redesign of the course included a format change from lecture-based to a blended style that allowed for more student discussions and active learning opportunities. In 2017, additional curricular revision increased student exposure to social issues from two class sessions deeply focused on social issues per semester to at least $80 \%$ of the class sessions (even if briefly). The focused class sessions have evolved from a stakeholder debate approach to exercises that emphasize a socio-technical systems framework, stakeholder value mapping, and empathy building.

This paper, using written student work, evaluates how the deepening of discussions revolving around social and ethical issues in sustainable urban development have affected student learning and their ability to integrate social and technical issues when thinking about the design of sustainable infrastructure. We evaluate and analyze student work from three activities that represent the evolution of curriculum in this course over the past three years. Results of the analysis suggest that short interventions in this technical course did increase students' awareness of social impact of technologies and students' understanding of complexity in infrastructure and technological changes.
\end{abstract}




\section{Introduction}

Since the report Our Common Future ${ }^{8}$ defined sustainable development, instructors have been trying to incorporate the concept of sustainability in their courses. The definition of sustainable development proposed by this report is accepted today and quite representative of the idea of sustainability, although some researchers think this definition may be too broad and prefer the term sustainable communities instead ${ }^{9}$. The report recognized three dimensions of sustainable development -environmental, economic, and social- additionally recognizing that a balance between these three dimensions must exist so that true sustainability can be achieved ${ }^{4,8}$. In the 1990s, universities around the world called for action to promote sustainable development ${ }^{10}$. More than 30 years after the impactful United Nations report was released, many U.S. engineering professional societies recognize sustainable development in their missions, core values, or code of ethics ${ }^{11,12,13}$, and sustainable practices are common in the engineering profession. Today, students arrive at universities in the U.S. with at least some conceptual knowledge of sustainability.

There are numerous examples of the environmental and economic pillars of sustainability being successfully incorporated into engineering curricula ${ }^{14,15,16,17,18,19}$. Both the economic and environmental dimensions of sustainability easily fit into an engineering program. However, due to the nature of technical courses, and the fact that program accreditation reinforces skills such as problem-solving, it can be quite challenging to fully incorporate the macro-ethical social dimensions of sustainable development ${ }^{3,5,6}$. In this study, we focus on the challenge of integrating macro-ethical socio-technical thinking skills through stakeholder value mapping ${ }^{20,21,}$ 22. This challenge is not unique to courses focused on sustainability. The challenge of integrating macro-ethical socio-technical thinking is common to all engineering curriculum ${ }^{23,24,25}$. Previous work on the integration of macro-ethical issues into engineering courses have fallen into two broad categories: 1) understanding institutional patterns of macro-ethical interventions in engineering curriculum ${ }^{26,27,28}$ and more fine-grained qualitative analyses of individual courses and activities. The latter group of studies have covered, for example, the integration of macroethical issues through case studies ${ }^{29}$, role play ${ }^{30}$, design work ${ }^{31}$, creative writing ${ }^{32}$, and more traditional modes of content delivery such as readings, lectures, and discussion ${ }^{33}$. More specifically, Bielefeldt has shown that integrating sustainability and ethics modules into first year engineering courses can increase student identification with these concepts, including the social dimensions of sustainability ${ }^{34,35}$. Nonetheless, while understanding stakeholder perspectives and socio-technical system complexity is often a component of these activities and courses ${ }^{36}$, there is very little fine-grained analysis of how stakeholder value mapping exercises can influence engineering student's appreciation of stakeholder diversity and socio-technical system complexity. While our focus here is on a civil and environmental engineering course, our study has implications for engineering curriculum in general. More specifically, though, we discuss here an attempt to use stakeholder value mapping exercises to equally represent all three dimensions of sustainable development in a technical engineering course.

The study reported here aims to answer the following two research questions related to using stakeholder value mapping exercises as short-term instruments for integrating macroethical issues into technical course. Does stakeholder value mapping:

1) improve student socio-technical thinking skills, which involves increasing student awareness of social-political factors and multiple stakeholder perspectives that influence engineering? 
2) develop student ability to identify second-order effects, defined here as indirect connections and consequences beyond direct cause and effect relationships ${ }^{37}$, associated with socio-technical complexity? Socio-technical system complexity, in this case, includes identifying, connecting, and understanding socio-political factors, multiple stakeholder perspectives, and uncertainty associated with the systems and products that engineers build ${ }^{38}$.

To answer these questions, we analyzed student data from three activities that represent the evolution of curriculum in a sophomore level Engineering and Sustainability course over the past three years. The main goals for the activities were to a) increase students' recognition of social-political factors and stakeholder diversity that influences engineering (Research Question 1); b) develop students' empathy for diverse stakeholders (not directly addressed in this paper); c) increase students' appreciation of the complexity of socio-technical systems (Research Question 2).

\section{Methods}

\section{Course History}

The study took place in a required sophomore-level course in a Civil and Environmental Engineering Department at a major research university. This course was created in 2003 with the title Applied Engineering Science ${ }^{7}$. The course addressed several issues, including preparing students for the Fundamentals of Engineering exam and for the upper-level environmental engineering courses. This course also fulfilled several new ABET requirements ${ }^{3,7}$. In 2010, the department rolled out a revised version of the course, which included a new name, Engineering for Sustainability. In 2015, the course was completely redesigned by Andrade. The redesign included both content and pedagogical changes. Starting in 2016, classes were redesigned to replace lecture-based student interaction with a blended learning scenario. According to the personal experience of the instructor of the course discussed in this paper (Andrade), second-year students and transfer students enrolled in the course tended to conflate sustainability with environmental protection (also observed by Bielefeldt ${ }^{34}$ ). However, around the middle of the semester, students started to recognize that true sustainable development was more complex than what they initially thought. Moreover, the instructor recognized a need to address the lack of student interaction with the social dimension of sustainability. In 2017, Andrade's additional curricular revision increased student exposure to social issues to at least $80 \%$ of the class sessions (even if briefly in each session). The focused class sessions have evolved from a stakeholder debate approach to exercises that emphasize a socio-technical systems framework, stakeholder value mapping, and building the students' ability to understand others' positions and feelings (empathy).

\section{Participants and Context}

In the fall of 2017, 50 students participating in the Engineering for Sustainability sophomore-level course participated in several in-class stakeholder mapping activities. The main goal of these activities was to increase students' awareness of social issues related to sustainable development in the civil and environmental engineering context. This paper focuses on the content analysis of three classroom activities focused on the social dimension of sustainability. 


\section{Activity 1 - Policy Complexity of an Ethanol-from-Biomass Production Process}

The first activity with a social-technical focus, Woody Biomass as a System, was taken from a University of Florida extension program educational workbook: Should We Use Wood for Energy? A High School Education Program ${ }^{39}$. In class, students were divided into groups of 2-3 students and received cards representing three main components of a wood-to-ethanol system and various stakeholder inputs and outputs for each component (Table 1). The students were asked to construct their wood-to-ethanol system with the cards provided. The activity also included four different worksheets; each presented a different government policy scenario that would impact the wood-to-ethanol system. In these worksheets, students were asked six questions that focused primarily on how the policies would impact each component of the system and the social, environmental, and economic impacts.

Table 1 - Summary of all activities reported.

\begin{tabular}{|c|c|c|c|c|}
\hline \multirow{2}{*}{$\begin{array}{l}\text { Activity } 1- \\
\text { Ethanol from } \\
\text { Biomass } \\
\end{array}$} & \multirow{2}{*}{$\begin{array}{l}\text { Activity } 2- \\
\text { Wind Farm }\end{array}$} & \multicolumn{3}{|c|}{ Activity $3-$ EVs and AVs } \\
\hline & & Day 0 & Day 1 & Day 2 \\
\hline $\begin{array}{l}\text { - Group activity } \\
\text { - Systems game } \\
\text { - Worksheet with } \\
\text { questions }\end{array}$ & $\begin{array}{l}\text { - Group activity } \\
\text { - Reading of } \\
\text { prep material } \\
\text { - Worksheet } \\
\text { with questions }\end{array}$ & $\begin{array}{l}\text { - Individual } \\
\text { activity } \\
\text { - Reading of } \\
\text { prep material } \\
\text { - Online } \\
\text { questions }\end{array}$ & $\begin{array}{l}\text { - Discussion and } \\
\text { modeling of } \\
\text { activity } \\
\text { - Reading of } 5 \\
\text { articles } \\
\text { - Group - Table } \\
\text { with } \\
\text { stakeholders } \\
\text { - Class discussion } \\
\text { - Individual } \\
\text { online questions }\end{array}$ & $\begin{array}{l}\text { - Introduction to } \\
\text { activity } \\
\text { - Individual in- } \\
\text { class questions } \\
\text { - Student group } \\
\text { discussion } \\
\text { - Reading of } 2 \\
\text { articles } \\
\text { - Worksheets with } \\
\text { different } \\
\text { scenarios } \\
\text { - Class discussion } \\
\text { - Individual } \\
\text { online questions }\end{array}$ \\
\hline
\end{tabular}

Activity 2 - Installation of a New Wind Energy Farm in the State of New York

The second activity with a social-technical focus was developed by the instructor (Andrade) based on information found on the Lighthouse Wind website ${ }^{40}$ and other news websites reporting about the construction of the facility. Students were divided into groups of 3-4 and received background information about the company building the new wind farm facility, an estimate of potential economic and environmental impacts of the facility, and information conveying the local community's feedback on the prospective facility (Table 1). For this activity, non-human stakeholders were not considered. Student groups were then asked four questions that focused on stakeholder identification and the impact of the wind farm on the stakeholder in the sustainability context (social, environmental, and economic impacts.)

\section{Activity 3 - Electric and Autonomous Vehicle Integration into Existing Socio-Technical Infrastructure}

The third activity with a socio-technical focus was developed by Andrade and Tomblin, integrating the sustainability and environmental engineering expertise of the course instructor 
(Andrade) with the science and technology studies expertise (social sciences) of the invited lecturer (Tomblin). This activity consisted of two in-class days with several assessments. In preparation for the first day of the activity, students were provided with an article that presented examples of socio-technical thinking ${ }^{41}$.

On Day 1 of the activity, instructors led a discussion on the socio-technical system article and modeled a stakeholder mapping activity (Table 1). Students read five articles about Electric Vehicle (EV) adoption ${ }^{42,43,44,45,46}$. The articles provided students different stakeholder perspectives along with information about infrastructure needs, economic considerations, environmental concerns and benefits, and social issues. Students prepared a table with 10-20 different stakeholders involved in EV adoption, the potential issues for the stakeholders, the relationship of the stakeholder with infrastructure, and if they thought the stakeholder would be in favor, against, or unsure of adopting EVs. Instructors followed the student activity with a discussion of the results. After class, the students had to reflect on the activity through an online questionnaire (Table 2).

Instructors led Day 2 with a short introduction to autonomous vehicles (AVs) and the status of the technology. Students were asked to answer four questions individually so that they could start the thought process. Students were then placed in groups of 3-5 where they discussed their individual answers with each other. After this short discussion, students were instructed to read two articles that described several social issues related to $\mathrm{AVs}^{47,48}$. After discussing the articles, each group received a worksheet describing a specific EV/AV adoption scenario. Four different scenarios were provided (each group had one scenario). Each scenario had a oneparagraph description with some details about social, economic, and environmental changes that could occur. As a group, in the worksheet provided, students were asked to identify how real estate; media, entertainment, and marketing; and middle-income families would be positively and negatively impacted. They were also asked to think of two stakeholders they had identified in Day 1 and describe how they would be impacted by this new scenario (both positively and negatively). The instructors concluded the class by reinforcing that sustainable development cannot be achieved through technological solutions alone and should address different stakeholders and socio-technical system complexity. The content of the class and the discussion was also linked to the sustainable development goals developed by the United Nations ${ }^{49}$. After class, students had to reflect on the stakeholder value mapping exercise through a series of online questions (Table 2).

Analysis

Activities 1 and 2 provided the inspiration for this study and the development of Activity 3. After leading Activities 1 and 2 in class, Andrade noticed students were not identifying sociopolitical issues related to stakeholders. A brief discussion of the results of these two activities is presented below and provide a baseline of comparison to student work in Activity 3. Student data from Activity 3 was analyzed using thematic coding ${ }^{50}$. We defined the coding themes based on the overall learning outcomes of Activity 3. In general, we wanted to assess student change in their ability to identify social and political factors that influence the implementation of technology and socio-technical complexity and uncertainty. Other themes, such as infrastructure, technology, environment, and economics, were coded because these were concepts we expected students to focus on by default prior to the stakeholder mapping activities. Measuring these themes provided us with a baseline comparison of themes we expected students to talk about more frequently relative to socio-political factors prior to Activity 3 . The codes we used to 
analyze student data were: environmental, economic, social, political/power, infrastructure, technology, complexity, uncertainty. In order to validate the coding process, the authors coded the student work separately and compared notes. After the coding was completed, the authors counted the number of student phrases in each category, and calculated the percentage of each code relative to the total. Both authors noted similar trends when coding data, with a few exceptions. As a result, we are reporting here the codes for Andrade only. Table 2 lists the questions that were coded. Questions 1,2, and 4 were compared to show how the socio-technical system activities influenced student use of the eight thematic codes and if the activities increased students' identification of socio-political and stakeholder influences on engineering. Questions 3 and 5 were used to analyze student appreciation of socio-technical system complexity and the second-order influences of the technologies.

Table 2 - Questions that were asked and analyzed through thematic coding during Activity 3 about EVs and AVs. Table also shows how the authors will refer to the questions henceforth (question code).

\begin{tabular}{|c|c|c|}
\hline \begin{tabular}{|l|} 
Activity \\
Timing
\end{tabular} & Question Code & Question Asked \\
\hline $\begin{array}{l}\text { Pre-class } \\
\text { quiz }\end{array}$ & $\begin{array}{l}\text { Question 1 (Day } \\
0)- \text { Benefits and } \\
\text { challenges of } \\
\text { electric vehicle } \\
\text { adoption }\end{array}$ & $\begin{array}{l}\text { [In our next class] we will discuss electric vehicles adoption. } \\
\text { List and discuss here some of the benefits and challenges } \\
\text { associated with the adoption of this technology (in a broader } \\
\text { transportation context, not only related to [university]'s } \\
\text { transportation system) }\end{array}$ \\
\hline $\begin{array}{l}\text { Quiz after } \\
\text { Day } 1\end{array}$ & $\begin{array}{l}\text { Question } 2 \text { (Day } \\
\text { 1) - Personal } \\
\text { opinion about } \\
\text { electric vehicles }\end{array}$ & $\begin{array}{l}\text { Based on our discussion, please answer the following two } \\
\text { questions: a) What did you learn from today's activity? } \\
\text { b) How did our discussion and activity change your personal } \\
\text { opinion about electric vehicles? }\end{array}$ \\
\hline $\begin{array}{l}\text { Quiz after } \\
\text { Day } 1\end{array}$ & $\begin{array}{l}\text { Question } 3 \text { (Day } \\
1) \text { - Electric } \\
\text { vehicle } \\
\text { community well- } \\
\text { being }\end{array}$ & $\begin{array}{l}\text { How does the electric vehicles adoption change the } \\
\text { community's well-being? Are these changes immediate or } \\
\text { long-term? }\end{array}$ \\
\hline $\begin{array}{l}\text { Quiz after } \\
\text { Day } 2\end{array}$ & $\begin{array}{l}\text { Question } 4 \text { (Day } \\
\text { 2) - Personal } \\
\text { opinion about } \\
\text { electric and } \\
\text { driverless } \\
\text { vehicles } \\
\end{array}$ & $\begin{array}{l}\text { Please write a } 250 \text {-word paragraph on how the class activities } \\
\text { held on [the last two class sessions] changed your opinions } \\
\text { and feelings about electric and driverless cars. }\end{array}$ \\
\hline $\begin{array}{l}\text { Quiz after } \\
\text { Day } 2\end{array}$ & $\begin{array}{l}\text { Question } 5 \text { (Day } \\
\text { 2) - Driverless } \\
\text { vehicle } \\
\text { community well- } \\
\text { being }\end{array}$ & $\begin{array}{l}\text { How does the driverless vehicles adoption (and the } \\
\text { infrastructure changes that accompany it) change the } \\
\text { community's well-being? Are these changes immediate or } \\
\text { long-term (write a 250-word paragraph to answer these } \\
\text { questions)? }\end{array}$ \\
\hline
\end{tabular}




\section{Findings and Discussion}

\section{Results from Earlier Activities: Inspiration for Further Study}

\section{Activity 1 - Policy Complexity of an Ethanol-from-Biomass Production Process}

The main goal of this activity was for students to start recognizing system complexity, which was achieved and can be easily identified in the student work. The last three questions of the student worksheets related directly to the three dimensions of sustainability: environment, economy, and society. For the purposes here, out of all the questions asked in the student worksheets, we were most interested in the last question: How do these changes affect the community's well-being? Are these changes immediate or long-term? There were 23 group worksheets collected by the instructor. Only 13 groups $(56.5 \%)$ were able to complete the assignment and answer this question. All groups, with one exception, answered this question in terms of the environment and economy. In general, answers defined community well-being as an environmental gain, for example, better air quality is good for the community. Economically, more jobs were seen by the students as good for the community. At times, students voiced a conflict between the economy and the environment. For example, students thought that in the short-term people could lose their jobs (negative impact of the policies), but in the long term the air would be cleaner. The one exception that can be considered a reference to social issues was, "more recreational [illegible] over a long time." This student group recognized a social impact, but the reference is superficial.

Environmental and economic issues do impact communities' well-being, so students were not incorrect to mention those issues in the last question of the assignment. However, it was the goal of the instructor that students would recognize this question as more related to social issues, since they were specifically asked about the environmental and the economic impact of the policies in the two previous questions. We expect this question will be revised in future semesters to represent the instructor's goal more clearly. However, the lack of social references is of concern and reinforced that social issues should be more intentionally and explicitly addressed in the course. These results, in part, led to the subsequent class activities.

\section{Activity 2 - Installation of a New Wind Energy Farm in the State of New York}

The main goals of this activity was to introduce the term "stakeholder" as language that would be used in future classes and to increase students' awareness of the diversity of stakeholders impacted by a technology. The instructor collected and assessed 17 group worksheets for this activity. Students were asked four questions; however, we only focus here on one of the questions: "Choose a stakeholder (that was not easily identified in the text) and explain how this stakeholder may be impacted by this wind power plant." All student groups answered this question with at least one economic reference. For the most part, students saw the construction of a wind farm as an economic gain, improving job outlook not only for people that would be working in the wind energy facility, but also for people providing services in the region. About $35.3 \%$ of the responses contained an environmental reference, for the most part considering a wind farm beneficial to the environment due to the possible reduction of fossil fuel use. However, students were also exposed to information regarding environmental groups that protested against this wind farm due to concern with bird killings. Therefore, some students viewed the wind farm as potentially having a negative impact on the environment. In these cases, 
environmental concerns were associated with bird killings and presented as a conflict with the potential economic gain of the region.

In terms of social references, only two out of 17 answers were social in nature. One group mentioned people that use the nearby lake recreationally would be impacted, however, the group did not say how people would be impacted. Another group mentioned that "public image of politicians" could be impacted, but the group did not elaborate how. The low number of social references could be in part explained by how the activity was structured and what information was provided to students. Social impact was discussed in class, but the written information provided to the students contained factual data on both economic and environmental impacts. It is important to note though that, in this question, students were specifically asked to identify stakeholders that were "not easily identified in the text" provided. Since students were not extensively encouraged to think about the social impact of the wind farm or other technologies, it is understandable that social references would be rare and superficial. Based on Activity 1 and 2 and past semesters, it was clear to Andrade that students needed a deeper dive into the sociopolitical complexity of sustainable technologies and infrastructure, therefore, Activity 3 was developed in collaboration with a trained social scientist (Tomblin).

\section{Activity 3}

\section{Research Question 1: Socio-political and stakeholder influences on engineering}

Overall, students demonstrated greater recognition of social, political, and socio-technical system complexity because of the activity (Table 3). Student pre-activity responses (Question 1, Day 0) about the benefits and challenges of EVs mainly focused on technological (19.0\%), environmental (21.4\%), and economic $(26.2 \%)$ issues. The activity shifted student focus away from economic (Day $1=4.9 \%$, Day $2=14.9 \%$ ) and technical issues (Day $1=5.6 \%$, Day $2=$ $13.4 \%$ ) toward social (Day $1=12.3 \%$, Day $2=24.5 \%$ ) and socio-technical complexity (Day $1=$ $35.2 \%$, Day $2=14.9 \%$ ). Environmental concerns continued to be a student focus on Day 1 $(21.0 \%)$ but dropped off slightly on Day $2(13.4 \%)$ when the topic of autonomous vehicles was introduced. Student recognition of political factors increased during the activity, but sustained only a low level of emphasis, suggesting that stakeholder value mapping alone doesn't alert students to the power dynamics among socio-technical actors (Table 3).

Over Day 1 and Day 2, students personally reported appreciating the diversity of stakeholders involved in the development and implementation of both EVs and AVs. A typical revelation stated, "I never really considered how many different organizations directly, and indirectly, influence/impact the change to EV's from gas-run cars." (Student 10, Question 4, Day 2 ). Both the number and specificity of stakeholders that students considered increased over the two-day exercise (23 for Day 0, 32 for Day 1, and 38 for Day 2). As seen with comparing Question 1, Day 0 with Question 2, Day 1 and Question 4, Day 2, students began to appreciate the diversity of energy and business sectors that might be affected by a transition to EVs and/or AVs. Less evident is a deeper appreciation for the diverse types of people that might be impacted or have an impact on the transition. However, with the Day 2 activity, where students were confronted with specific stakeholders, there was more recognition of how these technologies interacted with different types of specific stakeholder groups and geographic situations (urban vs. rural). In other words, there were less generalization about stakeholders (e.g., average 
consumer, people, society, etc.) and more specific identification of stakeholders (e.g., truckers, construction workers, skilled technicians, etc.)

Table 3 - Percentage of student text for each coding theme for question 1, 2, and 4 during Activity 3 (Coded by Andrade).

\begin{tabular}{|l|c|c|c|c|c|c|}
\hline & \multicolumn{2}{|}{$\begin{array}{c}\text { Question 1 (Day 0) - } \\
\text { Benefits and } \\
\text { challenges of electric } \\
\text { vehicle adoption }\end{array}$} & \multicolumn{2}{c|}{$\begin{array}{c}\text { Question 2 (Day 1) - } \\
\text { Personal opinion about } \\
\text { electric vehicles }\end{array}$} & $\begin{array}{c}\text { Question 4 (Day 2) - } \\
\text { Personal opinion about } \\
\text { electric and driverless } \\
\text { vehicles }\end{array}$ \\
\hline & Count & $\%$ & Count & $\%$ & Count & $\%$ \\
\hline Environmental & 53 & 21.4 & 34 & 21.0 & 35 & 13.4 \\
\hline Economic & 65 & 26.2 & 8 & 4.9 & 39 & 14.9 \\
\hline Social & 21 & 8.5 & 20 & 12.3 & 64 & 24.5 \\
\hline Political/power & 4 & 1.6 & 9 & 5.6 & 16 & 6.1 \\
\hline Complexity & 26 & 10.5 & 57 & 35.2 & 39 & 14.9 \\
\hline Uncertainty & 0 & 0 & 19 & 11.7 & 12 & 4.6 \\
\hline Infrastructure & 32 & 12.9 & 6 & 3.7 & 21 & 8.0 \\
\hline Technology & 47 & 19 & 9 & 5.6 & 35 & 13.4 \\
\hline Total & $\mathbf{2 4 8}$ & $\mathbf{1 0 0}$ & $\mathbf{1 6 2}$ & $\mathbf{1 0 0}$ & $\mathbf{2 6 1}$ & $\mathbf{1 0 0}$ \\
\hline
\end{tabular}

Recognizing stakeholder diversity is important, but it is also important to gauge what students are saying about stakeholders. Are they saying anything qualitatively different than they did before the activity? In our estimation, many of the students, but not all, provided relatively more nuanced perspectives about the interaction between the social and the technical. For example, Student 17 said:

"I found it [Activity 3 exercises] very informative to view these 2 issues from a sociotechnological standpoint, it gave me a new perspective to view not only these technological issues but all issues. I learned that for every technological development/breakthrough there are many organizations and stakeholders who are involved and affected by the development all with different cultural views. These cultural views are based on their core values, which are formed from their life experiences. This makes these seemly simple developments much more complex." (Student 17, Question 4, Day 2)

Student 17 makes the leap that cultural values and life experiences shape what people see in emerging technology. This student also took the nuanced step to realize that social factors impact the development of technology as well as technology impacts society. However, many students did not identify this reciprocal relationship between technology and society. Instead, they often described interactions in a one-way fashion: EVs and AVs would impact or affect people: "I never really thought about how changing over to electric and driverless cars would impact so many different aspects of life." (Student 10, Question 4, Day 2). Here, people and organizations have very little agency in how the technology influences them. While there is recognition that the impacts are more complex than originally thought, technology is seen as determining the outcome. Student statements such as these reveal that many students may not recognize the subtle power relationships between technologists and the society that they reproduce $^{51}$. 
However, some students did develop more nuanced sensibilities about how power operates in decision-making about technology. For instance, some students started thinking about the adoption of technology as a decision, which is a recognition that someone somewhere has the power to influence the direction of technology. Student 20, Question 2, Day 1 saw stakeholder involvement in the development and implementation of EVs like this: "I learned that there are seemingly countless stakeholders, or groups involved, who are directly impacted by the decision." So rather than the technology impacting stakeholders, as was stated by Student 10 above, stakeholders are impacted by a decision. Currently, we have not analyzed to what extent either perspective (technological determinist or social constructivist) is used by students, but it is important to note because most people and engineering students tend to give more agency to technology than to people $\mathrm{e}^{52,53,54,55}$.

Students also told more explicit stories about power. On Day 2, Student 7 provided these thoughts on what it might mean to give up driving:

"Driving a car gives you the feeling of freedom. You go wherever you want experiencing excitement and adrenaline, but with driverless, we cannot have the same experience. I think we would become less skillful as we want as [sic] to implement robots or driverless cars on human activities. This would make [it] more difficult to interact with other people. I think that we will reach a point when humans are useless to perform jobs." (Student 7, Question 4, Day 2)

According to this student, driverless technology has power over humans. We would lose both freedom and skills. There is no room for human agency here, but there is recognition that there would be a loss of agency. A few students recognized the role that corporations play in the adoption of technology: "I learned a fair amount about the large power roles that major industries like the auto and oil industry has [sic] over the consumers." (Student 6, Question 2, Day 1). But overall, the idea that political factors influence the direction of technology was relatively uncommon during the activity (Table 3 ).

Another trend in the data is that while on Day 1 of the activity the majority of students made claims about appreciating the large number of stakeholders involved in the implementation of emerging technology, there was generally a lack of depth to students' portrayal of stakeholders. On Day 2, however, when the focus was on a few stakeholders, students made more empathetic expressions. For example, after the Day 2 activity, Student 40 thought about the level of agreement it would take for AVs to be adopted and what adoption might economically mean to a family:

"I don't think driverless vehicles are feasible for at least another decade politically, economically, and theoretically. To the extent of my knowledge, in order for the automated vehicles to work properly, there cannot be any driver-operated vehicles, and that means every single person agree to forfeit their right to drive the vehicle, as well as afford it for every person in the family. It would be very convenient, and a lot safer than driver-operated vehicle; however, it's still a working process. Driverless, electric vehicles will take even longer for us to adapt to because that would require many changes in infrastructure." (Student 40, Question 4, Day 2) 
Similarly, some students expressed a variety of concerns that were not directly from their own experience, such as issues with privacy, job loss, anxiety, inequality, rural versus urban experiences, etc. For some students, the importance of being "self-reflective" became an important aspect of technological development and implementation. However, while the activities may have increased social awareness and the appreciation of diversity of stakeholders involved, we would have to do further studies to learn if the activity increased student empathy for stakeholders.

\section{Research Question 2: A Deeper Dive into Socio-Technical Systems - Students Recognition of Second-Order Social Impacts}

In Activity 1, students were asked about the impact of certain government policies on the community's well-being. As reported earlier, only one answer out of 13 contained a social reference. Since the students had been asked about community well-being in a social context in Activity 1, we took this opportunity to assess if Activity 3 pushed student definitions of community well-being beyond environmental and economic issues. In the post-activity reflections, we included the same language in two questions of Activity 3: questions 3 and 5 (Table 1). One of the goals of Activity 3 was to determine if student's text coded as social would increase and if the content of students' text would include second-order social impacts. Question 5, Day 2 contained more student coded text: 322 coded for Question 5 versus 150 for Question 3, Day 1 (Table 4). The main reason for this result may be in how the questions were presented to the students. Even though students had no time limit to answer both questions and the assignment was completed online, Question 5 mentioned in the text that students should write a 250-word paragraph while Question 3 did not. This gave students the opportunity (or perhaps forced them) to elaborate their thoughts, providing the instructor with a more thorough picture of student perspectives on the activity.

Table 4 - Counts and percentage of student coded text for each coding theme for questions 3 and 5 during Activity 3 (coded by Andrade).

\begin{tabular}{|l|c|c|c|c|}
\hline & \multicolumn{2}{|c|}{$\begin{array}{c}\text { Question 3 (Day 1) - } \\
\text { Electric vehicle } \\
\text { community well-being }\end{array}$} & \multicolumn{2}{c|}{$\begin{array}{c}\text { Question 5 (Day 2) - } \\
\text { Driverless vehicle } \\
\text { community well-being }\end{array}$} \\
\hline & Count & $\%$ & Count & $\%$ \\
\hline Environmental & 47 & 31.4 & 22 & 6.8 \\
\hline Economic & 22 & 14.7 & 55 & 17.1 \\
\hline Social & 28 & 18.7 & 101 & 31.4 \\
\hline Political/power & 8 & 5.3 & 28 & 8.7 \\
\hline Complexity & 14 & 9.3 & 20 & 6.2 \\
\hline Uncertainty & 5 & 3.3 & 12 & 3.7 \\
\hline Infrastructure & 14 & 9.3 & 52 & 16.2 \\
\hline Technology & 12 & 8.0 & 32 & 9.9 \\
\hline Total & $\mathbf{1 5 0}$ & $\mathbf{1 0 0}$ & $\mathbf{3 2 2}$ & $\mathbf{1 0 0}$ \\
\hline
\end{tabular}

Overall, the percentage of "Economic", "Political/power", "Complexity", "Uncertainty", and "Technology" references remained relatively similar across the two questions. "Environmental", "Social", and "Infrastructure" references had significant changes from Day 1 
to Day 2 and will be discussed in more detail. Although, in Question 5, students were asked only about the impact of AVs, many students provided insights for both EVs and AVs, which is not surprising given students discussed both technologies on Day 2. This can help explain the increase in references to infrastructure (from 9.3\% to 16.2\%). "Environmental" references decreased significantly from Question 3, Day 1 to Question 5, Day 2 (from 31.4\% to 6.8\%). This result is not surprising as students generally recognize EV technology as environmentally friendly, associating the use of EVs with the reduction of fossil fuel use (revealing statements with a linear notion of cause and effect between EV use and improved air quality and therefore environmental gain).

Students made 28 social references in Question 3, Day 1 (18.7\% of total) and 101 social references in Question 5, Day $2(31.4 \%)$. This was a significant increase in social remarks and it is safe to say that, at least in the short term, the Day 2 activities made students more aware of social impacts of technology and people's decisions about technological implementation (these results are consistent with the Question 1, 2, 4 data as well). While several of the social statements were of little depth, some students clearly spent time thinking about possible social impacts of AVs. For example, Student 26 provides us with an example of second-order thinking:

"...there would be much more controversy in legislation regarding control of these vehicles and access to information about location, destination, and occupants of each vehicle. There would be a demand for high security for the vehicle controls because so much damage could be done by hackers taking control of a vehicle and using it as a weapon...

Long-term effects would be earning the trust of the public... Laws would need to be developed regarding a person being the only passenger in a self-driving vehicle while under the influence of drugs or alcohol. Society may become so accustomed to not having to drive that they aren't paying enough attention to the road in case a problem arises that requires manual override of the controls." (Student 26, Question 5, Day 2)

Student 26 introduces a conversation about information privacy, a current and relevant social discussion in the U.S., and later he/she writes about the ability of hackers to access vehicles and use them as weapons. The student thinks about how policy would have to be changed to address the changes in how people would use the technology (e.g., people under the influence). This deep thought process represents this student's ability to make profound connections between the technology and how people interact with it. This student understands that AVs would collect private information and other people could have access to that data and some could use that information for other purposes than the intended one. Student 26 shows a pattern of making more than one direct connection for each of the issues that she/he brings up. This pattern was unique to this student, and although it does not represent the entire class, it showcases that students were given the opportunities to really think about possible societal impacts of EVs and AVs.

On both days of Activity 3, per the directions of the instructors, students discussed the impacts of EVs and AVs on specific stakeholders, not impacts on the broader community. The intention of the instructors was that if the students identified specific stakeholders, they would spend more time on the possible effects that the technologies could have in each stakeholder and this would allow for more second-order thinking. However, when asked to reflect on their discussions in retrospect, students were asked about the impact on community well-being (much more broad than specific stakeholders). A result of this choice was that students that defined 
community more specifically were able to develop more insightful thought processes (and translate them to the writing assignment). For example, Student 32, Question 3, Day 1 started his/her answer stating that the impact would depend on the community. Even though Student 32 did not develop the social impacts of the technologies on specific stakeholders, he/she defined the community in two different ways: those living in New York City and those living in the region where lithium mines are explored. The social impact of EVs and AVs was more clearly articulated for each of the defined communities, reinforcing that the activities were able to deepen students' identification of social impacts. Moreover, this student showed second-order thinking process that included the relationship between electric vehicles, the need for efficient batteries, the fact that material needed for the batteries is mined in a different country and that the people that mine these materials have different priorities than users of electric cars and their lives are impacted in different ways. This level of thinking was more representative of other students in the class and were partly due to students' interest and background knowledge, partly due to assigned readings, and partly due to how activities were led.

\section{Future Work}

As the study moves forward, we will continue to refine the above data analysis. We also plan to enhance the study in the following ways:

1. We will use open coding methods to derive a more in-depth, systematic analysis of student responses in Activity 3. Through this analysis, we hope to gain a better understanding of what changes in student recognition of social interactions means: a) what are students writing about socio-political issues and socio-technical complexity? b) how substantive are student responses about socio-political issues and socio-technical complexity (enhancing the second research question)?

2. Activity 3 represents a snapshot of student reflections on socio-political issues. So, our analysis cannot say much about whether student will sustain socio-technical systems thinking throughout the course and beyond. Andrade included questions on her final exam that asked students to use socio-technical systems thinking to analyze a problem. We plan to analyze these questions to determine to what extent Activity 3 had a lasting impact on student integration of social issues with technical issues.

3. In Andrade's spring 2018 Engineering and Sustainability course, we will again include all three activities. We will include lessons learned from the first iteration of this study to refine our methods and analysis.

\section{Conclusion}

It is clear that incorporating the social dimension of sustainable development in technical engineering courses is both important and complex. After students were exposed to the stakeholder value mapping exercises described in this study, they showed an increased awareness of social factors that influence engineering, a more vivid appreciation of system complexity, developed a slightly deeper understanding of what social impacts are, and were able to translate to text second-order social impacts of EVs and AVs. Aside from mentioning more social issues in their answers, some students were also able to develop deeper thinking about the reciprocal relationships between humans and technology. In addition, we found that when students defined community in a specific way or identified specific stakeholders, they were able 
to articulate more nuanced and complex social relationships with engineering and technology. However, we remain cautious about the efficacy of short-term stakeholder value mapping exercises, as the majority of the students provided a superficial level of insight about stakeholder relationships to socio-technical systems. Furthermore, despite increased awareness in social influences on engineering, students did not demonstrate an appreciable increase in awareness of political factors that influence engineering. This suggests that stakeholder value mapping alone is not sufficient for student identification of power relationships among stakeholders. Because of these findings, we believe that students need more sustained exposure to socio-technical relationships throughout engineering curriculum to increase their sensitivity to and awareness of these relationships. Lastly, it is important to note that students were influenced by how questions were asked and what kinds of text they were exposed to; therefore, instructors need to carefully choose readings and assignments that will lead to a balanced, well-structured activity with measurable and substantive outcomes.

\section{References}

1. Vanderburg, W. H. (1999). On the measurement and integration of sustainability in engineering education. Journal of Engineering Education, 88(2), 231-235.

2. Murphy, C. F., Allen, D., Allenby, B., Crittenden, J., Davidson, C. I., Hendrickson, C., \& Matthews, H. S. (2009). Sustainability in engineering education and research at US universities. Environ. Sci. and Technol. 43, 5558-5564.

3. ABET 2015. Criteria for Accrediting Engineering Programs Effective for Reviews During the 2016-2017 Accreditation Cycle. ABET Engineering Accreditation Commission. www.ABET.org

4. United Nations (2015). Resolution 70/1: Transforming our world: the 2030 agenda for sustainable development.

5. Bondehagen, D. L., Komisar, S. J. (2017). Continuing Assessment of Sustainability Skills in the Environmental and Civil Engineering Curriculum. Paper presented at 2017 ASEE Annual Conference \& Exposition, Columbus, Ohio.

6. Cornejo, P. K. (2017). Integrating Economic and Environmental Sustainability for Undergraduate Education. Paper presented at 2017 ASEE Annual Conference \& Exposition, Columbus, Ohio.

7. Seagren, E. A., Davis, A. P. (2011). Integrating Fundamental Science and Engineering Concepts into a Civil Engineering Sustainability Course. J. Prof. Issues Eng. Educ. Pract. 137, 183-188.

8. United Nations (1987). Report of the World Commission on Environment and Development: Our Common Future.

9. Bridger, J. C., Luloff, A. E. (1999). Toward an Interactional Approach to Sustainable Community Development. Journal of Rural Studies 15, 377-387.

10. Steinemann, A. (2003). Implementing Sustainable Development through Problem-Based Learning: Pedagogy and Practice. J. Prof. Issues Eng. Educ. Pract. 129, 216-224.

11. Workers, N. A. (2017). American Society of Civil Engineers Code of Ethics. Washington, DC: ASCE.

12. Workers, N. A. (2012). The American Society of Mechanical Engineers Code of Ethics. Washington, DC: ASME.

13. Workers, N. A. (2003). Institute of Electric and Electronics Engineers Code of Ethics. Washington, DC: IEEE. 
14. Hua, I., Nies, L. (2017). Innovations in Environmental Engineering Education Programs. Paper presented at 2017 ASEE Annual Conference \& Exposition, Columbus, Ohio.

15. Cornejo, P. K. (2017). Integrating Economic and Environmental Sustainability for Undergraduate Education. Paper presented at 2017 ASEE Annual Conference \& Exposition, Columbus, Ohio.

16. Bondehagen, D. L., Komisar, S. J. (2017). Continuing Assessment of Sustainability Skills in the Environmental and Civil Engineering Curriculum. Paper presented at 2017 ASEE Annual Conference \& Exposition, Columbus, Ohio.

17. Burian, S. (2010). Teaching Sustainability and Sustainable Engineering Practice in the Civil Engineering Curriculum. Paper presented at 2010 ASEE Annual Conference \& Exposition, Louisville, Kentucky.

18. Hadgraft, R., Goricanec, J. (2007). Engineering Sustainability?! Paper presented at 2007 ASEE Annual Conference \& Exposition, Honolulu, Hawaii.

19. Sattler, M. L., Chen, V., C. P., Dennis, B. H., Mattingly, S., Rogers, K. J., Weatherton, Y. P., Rani, M., Kositkanawuth, K. (2012). Integrating Sustainability Across the Curriculum: Engineering Sustainable Engineers. Paper presented at 2017 ASEE Annual Conference \& Exposition, San Antonio, Texas.

20. Newberry, B. (2004). The dilemma of ethics in engineering education. Science and Engineering Ethics, 10 (2), 343-351.

21. Herkert, J.R. (2005). Ways of thinking about and teaching ethical problem solving: Microethics and macroethics in engineering. Science and Engineering Ethics, 11 (3), 373385.

22. Riley, D. (2008). Ethics in Context, Ethics in Action: Getting Beyond the Individual Professional in Engineering Ethics Education. Paper presented at 2008 ASEE Annual Conference \& Exposition, Pittsburgh, PA.

23. Cech, E. A. (2014). Culture of disengagement in engineering education? Science, Technology, \& Human Values, 39(1), 42-72.

24. Nieusma, D. (2015). Conducting the instrumentalists: a framework for engineering liberal education. Engineering Studies 7(2-3), 159-163.

25. Canney, N.E., M. Polmear, A.R. Bielefeldt, D. Knight, C. Swan, and E. Simon (2017). Challenges and Opportunities: Faculty Views on the State of Macroethical Education in Engineering. Paper presented at 2017 ASEE Annual Conference \& Exposition, Columbus, $\mathrm{OH}$.

26. Bielby, R.M., T.S. Harding, D.D. Carpenter, C.J. Finelli, Sutkus, J., Burt, B.A., Ra, E., and Holsapple, M. (2011). Impact of Different Curricular Approaches to Ethics Education on Ethical Reasoning Ability. Paper presented at 2011 ASEE Annual Conference \& Exposition, Vancouver, $B C$.

27. Bielefeldt, A.R., N.E. Canney, C. Swan, and D. Knight (2016). Efficacy of Macroethics Education in Engineering. Paper presented at 2016 ASEE Annual Conference \& Exposition, New Orleans, LA.

28. Bielefeldt, A.R., M. Polmear, D. Knight, N.E. Canney, and C. Swan. Incorporation of Ethics and Societal Impact Issues into First-Year Enigneering Course: Results of a National Survey. Paper presented at 2017 ASEE Annual Conference \& Exposition, Columbus, OH.

29. Warford, E.L. (2016). Ethics in the Classroom: The Volkswagen Diesel Scandal. Paper presented at 2016 ASEE Annual Conference \& Exposition, New Orleans, LA. 
30. Walther, J., S.E. Miller, N.W. Sochacka, and M.A. Brewer (2016). Fostering Empathy in an Undergraduate Mechanical Engineering Course. Paper presented at 2016 ASEE Annual Conference \& Exposition, New Orleans, LA.

31. Bielefeldt, A.R. (2016). Infusing Macroethical Ideas into a Senior Engineering Course. Paper presented at 2016 ASEE Annual Conference \& Exposition, New Orleans, LA.

32. Atwood, S.A., B. Read-Daily (2015). Using a creative fiction assignment to teach ethics in a first-year Introduction to Engineering Course. Paper presented at 2015 ASEE Annual Conference \& Exposition, Seattle WA.

33. Johnson, K., J. A. Leydens, B.M. Moskal, D. Silva, and J.S. Fantasky (2015). Social Justice in Control Systems Engineering. Paper presented at 2015 ASEE Annual Conference \& Exposition, Seattle, WA.

34. Bielefeldt, A.R. (2011). Sustainability Ethics Among First-Year Civil and Environmental Engineering Students. Paper presented at 2011 ASEE Annual Conference \& Exposition, Vancouver, BC.

35. Bielefeldt, A.R. (2010). Evolution of a Sustainability Focused First-Year Environmental Engineering Course. Paper presented at 2010 ASEE Annual Conference \& Exposition, Louisville, $K Y$.

36. Wilson, D. M.J. Kim, R.A. Bates, and E. Burpee (2014). How Engineering Students View Dilemmas of Macroethics: Links between Depth of Knowledge and Ethical Literacy. Paper presented at 2014 ASEE Annual Conference \& Exposition, Indianapolis, IN.

37. Allenby, B., Sarewitz, D. (2011). The Techno-human Condition. Cambridge, MA: The MIT Press.

38. Johnson, D.G., and J.M. Wetmore (2008). STS and Ethics: Implications for Engineering Ethics. In The Handbook of Science and Technology Studies, E.J. Hackett, O. Amsterdamska, M. Lynch, and J. Wajcman, eds. (Cambridge, MA: The MIT Press): 567-582.

39. Ireland, J. T., Monroe, M. C., Oxarart, A. (2010). Should We Use Wood for Energy? A High School Education Program. School of Forest Resources and Conservation. Florida Cooperative Extension Service, Institute of Food and Agricultural Sciences, University of Florida.

40. Lighthouse Wind. (2018, February 5). http://www.lighthousewind.com/

41. Neeley, K. A. (2010). Toward an Integrated View of Technology. In: Technology and Democracy: A Sociotechnical Systems Approach. Ed. by Neeley, K. A., Cognella, San Diego, CA. pp. 37-45.

42. Fung, B. (2017, September 11). As Hurricane Irma Bore Down, Tesla Gave Some Florida Drivers More Battery Juice. Here's Why that's a Big Deal. https://www.washingtonpost.com/news/innovations/wp/2017/09/11/as-hurricane-irma-boredown-tesla-gave-some-florida-drivers-more-battery-juice-heres-why-thats-a-bigdeal/?utm_term $=.25 \mathrm{e} 98 \mathrm{~d} 5 \mathrm{~b} 00 \mathrm{f} 8$

43. Wade, L. (2016, March 31). Tesla's Electric Cars Aren't As Green As You Might Think. https://www.wired.com/2016/03/teslas-electric-cars-might-not-green-think/

44. Drive Electric NYC (2018, February 5). Are Electric Cars Good for Society? http://www1.nyc.gov/html/ev/html/society/society.shtml

45. Randall, T. (2016, February 25). Here's How Electric Cars Will Cause the Next Oil Crisis. https://www.bloomberg.com/features/2016-ev-oil-crisis/

46. 3p Contributor. (2016, November 3). The Lifecycle Impact of Electric Vehicles. http://www.triplepundit.com/2016/11/lifecycle-impact-electric-vehicles/ 
47. Ashley, J. (2017, January 1). The Driverless Car Revolution Isn't Just About Technology It's About Society Too. https://www.theguardian.com/commentisfree/2017/jan/01/driverlesscars-boon-bane-coming-down-fast-lane

48. Eldredge, B. (2016, September 6). 5 Ways Driverless Cars Will Change Our Roads and Highways. https://www.curbed.com/2016/9/6/12804434/driverless-cars-highways-roadsuber-google.

49. United Nations Sustainable Development Goals. http://www.un.org/sustainabledevelopment/sustainable-development-goals/

50. Strauss, A. and J. Corbin (1990). Basics of Qualitative Research: Grounded Theory Procedures and Techniques. Newbury Park, California: SAGE Publications.

51. Gupta, A., Elby, A., Turpen, C., Philip, T. (2016). The Dynamics of Perspective-taking in Discussions on Socio-technical Issues. Paper presented at 2016 ASEE Annual Conference \& Exposition, New Orleans, LA.

52. Smith, M. (1994). Technological Determinism in American Culture. In Does Technology Drive History? The Dilemma of Technological Determinism, M. Smith and L. Marx (eds.). Cambridge, MA: The MIT Press: 1-37.

53. Nye, D. (2004). Why Technology Matters. Cambridge, MA: The MIT Press.

54. Schatzberg, E. (2006). Technik Comes to America: Changing Meanings of Technology Before 1930. Technology and Culture 47, 486-512.

55. Cohen, B., J.S. Rossmann, and K. Sanford Berhhardt (2014). Introducing Engineering as a Socio-technical Process. Paper presented at 2014 ASEE Annual Conference \& Exposition, Indianapolis, IN. 